\title{
И.И. Юкина
}

\section{ПРАВЕАНЫЕ МАРФА И МАРИЯ}

К^ЮчеВЫЕ СловА: Великие реформы, императорский Авор, русская аристократия, реформаторы, "шестидесятники", поколенческий призыв, поколенческое единство, традиции благотворительности, социальные инновации, Российское Общество Красного Креста.

АннотАция: Статья посвящена Аеятельности М.С. Сабининой - учительницы музыки Аетей императора Александра II и баронессы М.П. ФреАерикс - фрейлины императорского Авора, которые созАали Российское Общество Красного Креста. Праведные Марфа и Мария, как их называли при Аворе, основа^и организацию на совершенно новых Аля России принципах - как частную и добровольную. Основополагающей идеей Общества была идея права человека на жизнь, на свободу от жестокого, бесчеловечного и унижающего его Аостоинство обращения. Эта социальная инновация Авух придворных дам способствовала признанию в российском обществе идеи о неотьемемых правах человека и развитию гуманитарного права.

Российский модернизационный проект, начавшийся в конце 1850-х гг. оказал всеохватывающее влияние на общество. Серьезные культурные изменения того времени были производными Великих реформ, и сами в свою очередь влияли на прохождение реформ. Процесс формирования новых ценностей, изменение образа мысли, предписанного поведения медленно, но неуклонно происходил в различных слоях российского общества. Прежде всего, в образованных слоях, чутких к новым культурным веяниям и потому более подверженных культурным изменениям. Другими словами, реформы выступили внешними факторами культурных изменений в стране. Внутренними выступили новые идеи, носи-

Ирина Игоревна Юкина, кандидат социологических наук, Аоцент, Национальный исследовательский университет "Высшая школа экономики" в СанктПетербурге, irinayukina@gmail.com

DOI: 10.32608/2307-8383-2019-27-149-181 
телями которых были образованные, европеизированные представители преимущественно молодого поколения.

Благотворительная деятельность была респектабельной формой служения обществу и даже культурной нормой в придворных кругах XIX века. Императорская семья играла значимую роль в развитии филантропии и нередко демонстрировала достойные образцы благотворения, по большей части со стороны женщин - императриц и великих княгинь. В известном смысле филантропия была прерогативой высших сословий, т.к. для открытия добровольного благотворительного общества требовалось Высочайшее разрешение, поданное через Комитет министров. Для открытия благотворительного заведения, кроме того, обязательным было требование обеспечить его основным капиталом. Таким образом, только состоятельные люди с положением в обществе могли участвовать в благотворительности. После революционных событий в Европе в 1848 г. этой осторожной политике был положен конец - Николай I наложил запрет на учреждение новых благотворительных обществ.

Помимо чисто прагматической цели - сокращение нищенства, в филантропии высших сословий был и определенный идеологический посыл - демонстрация элитой общества христианской любви к ближнему своему «по великому примеру, данному Спасителем». Благотворительная деятельность строилась на основе принципов патернализма, контроля и назидания, т.е., на тех же, на которых держалось российское до-модерное общество.

Одна из базовых идей Великих реформ - идея всесословности нашла отражение в пореформенные годы и в вопросе благотворительности. По данным А. Линдермейер, царствование Александра II ознаменовалось небывалым ростом числа благотворительных организаций и учреждений, 


\section{Юкина И.И. Праведные Марфа и Мария}

которое неуклонно увеличивалось на протяжении периода 1856-1880 гг. Так, в 1856-1860 гг. было создано 24 новых благотворительных обществ, в 1861-1865 - 61, в 1866-1870 - 153, в 1871-1875 - 188, в 1876-1880 - 3271.

Несмотря на то, что указ 1848 г., запрещавший создание новых благотворительных обществ был отменен только в 1859 г., уже с середины 1850-х его нарушали, и нет сомнений, что с Высочайшего дозволения. В стране складывалось новое отношение к добровольным обществам. А. Линдермейер считает (и автор данной статьи согласна с ней), что это не было продуманной политикой признания общественных инициатив или поиска путей улучшения положения бедных и нуждающихся, а скорее ответ на давление со стороны общественности, роста количества ходатайств на открытие различных филантропических организаций. К тому же создание органов местного самоуправления - земского (1864) и городского (1870) способствовало развитию этого процесса.

\section{Поколение шестидесятников: новые идеи, новые веяния, новые чувствования}

Давление на авторитарную власть осуществлялось не только «извне» - со стороны различных слоев российского общества, но и «изнутри»- из самого близкого круга императора. Кто были эти люди, которые оказывали давление на государя, прямо и косвенно способствовали развитию социальных инициатив, смене культурной парадигмы в отношении прав и обязанностей подданных, изменению принципов благотворения?

1 Линдермейер. 1992: 285. 
В самом широком смысле это была образованная европеизированная элита, включенная в европейскую элиту, имевшая опыт жизни за границей. Эти люди принадлежали к лагерю «западников» и их целью было сблизить Россию с Европой с тем, чтобы Россия двигалась по тому же пути, по которому двигался «цивилизованный мир». В первую очередь к ним можно отнести так называемых «либеральных бюрократов», т.е. чиновников, которые продвигали реформы. Они придерживались либеральных взглядов и с вступлением на престол Александра II смогли занять высокие посты и начать либеральные преобразования. Среди чиновничества эти люди были в меньшинстве, но оказались достаточно влиятельны, чтобы определить политический курс государства в десятилетие после окончания Крымской войны.

Также к европеизированной элите можно отнести некоторых деятелей дворянского самоуправления, земского и городского самоуправлений, представителей высшей аристократии. Среди них было немало прагматиков, «людей дела».

Вслед за К. Мангеймом - классиком «поколенческого подхода», мы можем говорить о поколенческом единстве этой широкой когорты «шестидесятников». К. Мангейм считал, что кризисные события обусловливают новое видение и мышление молодого поколения. Поколение он определял как слой людей, сходство которых в значительной мере обусловлено сходством их жизненного опыта, общими ценностями, идейными соображениями, переживаемыми настроениями и единым социокультурным контекстом определенного исторического периода. Молодое поколение не просто проживает жизнь на одном временном отрезке, оно подвержено одинаковому влиянию одних и тех же событий интеллектуальной, социальной и политической жизни. Их личный выбор осуществляется в глубоких пластах интеллектуаль- 


\section{Юкина И.И. Праведные Марфа и Мария}

ной и духовной жизни своего времени, изменения происходят в ценностной и мотивационной сфере людей данного поколения. Мангейм писал, что «дух поколения» объединяет тех, кто прошел через одни и те же события, и этот «дух поколения» формирует поколенческие единства. Мы, вслед за Мангеймом говорим о поколенческом единстве «шестидесятников» принадлежавших к различным сословиям.

Мангейм доказывал, что без поколенческой истории, без учета особого влияния поколений на историю, нельзя многого понять из происходящего в прошлом, в частности, мотивацию деятельности людей.

Поколенческое единство объединяло людей разных социальных слоев. Женщины высших сословий в этом поколенческом призыве занимали особое положение в силу близости к власти и нахождению в эпицентре событий. Перед некоторыми из них, разделявших «дух поколения»в мангеймовском смысле, встали проблемы собственного самоопределения и участия в новых обстоятельствах жизни.

Формой женского общественного служения в то время могла быть только благотворительность. Как показывает наше исследование, ценности женщин и их идеализм формировали новые модели женского поведения, которые находили поддержку в их поколенческом призыве.

Сам факт того, что две придворные дамы выбрали в качестве своего жизненного пути служение обществу, говорит о том, что «дух реформ» захватил самые широкие слои подданных, включая двор.

Понять идеи и ценности, которыми руководствовались люди прошлого, мотивы их поведения и выбора, возможно только благодаря их личным документам. Статья написана, прежде всего, на основе писем, дневников и мемуаров обеих героинь и статьи современницы и биографа М.С. Сабининой 
Н.И. Алмазовой. Алмазова разбирала личный архив Сабининой в 1892 г. когда работала над историческим очерком к 25-летию создания Российского Общества Красного Креста (РОКК). Об этом она сообщила в конце брошюры:

Все изложенное мною .... я извлекла из бумаг, хранящихся у Марфы Степановны Сабининой. Ялта. 3 мая 1892 года².

Архив Сабининой до нас не дошел, поэтому все письма героинь в статье цитируются по этому источнику.

\section{Мария Петровна Фредерикс (1832-1903)}

Мария Петровна (ИлЛ. 1) стала фрейлиной императрицы Александры Федоровны в неполные 17 лет. Это была дань любви и привязанности императрицы к матери Марии Фредерикс баронессе Цецилии Владиславовне Фредерикс (Илл. 2), в девичестве графини Гуровской, подруги детства и статс-дамы. Цецилия Гуровская и императрица, в прошлом принцесса Шарлотта, дочь Фидриха-Вильгельма III выросли вместе при прусском дворе. Обе вышли «замуж в Россию»и всю жизнь были связаны нежной дружбой. Их дети были ровесниками и также как их матери росли вместе при дворе. 0 Марии Фредерикс говорили, что она «выросла на скамеечке у ног императрицы». Сама Фредерикс записала в своих воспоминаниях, что ей выпало счастливое детство при дворе, без «натянутостей этикета».

Судя по ее запискам, науками ее не мучили. Взгляды она имела монархические, боготворила Николая I, который был ее крестным отцом, почитала за «счастье слышать его ласковое и шутливое слово» и считала его человеком «добрым, простым и скромным» ${ }^{3}$. «Вообще учтивость и вниматель-

2 Алмазова. 1892: 24.

3 Фрелерикс. 1997: 290. 


\section{Юкина И.И. Праведные Марфа и Мария}

ность государя доходила до такой степени, что в настоящее время их и не поймут» ${ }^{4}$. Что касается политики Николая I, то она считала, что он «возвысил Россию в глазах Европы» 5 , его внутреннюю политику без мудрствований объясняла «отеческой заботой».

Сторонним наблюдателям Мария Фредерикс представлялась весьма заурядной свитской фрейлиной, не обладавшей никакими достоинствами. А.Ф. Тютчева, прослужившая фрейлиной 13 лет, чьи известные записки отличаются заинтересованным и критическим политики Николая I, писала:

Аве сестры Фредерикс <...> не обладают ни одним из физических или умственных Аостоинств, которые могли бы содействовать блеску, изяществу или Ааже просто приятности Авораб.

Обо всех фрейлинах императрицы Александры Федоровны Тютчева, будучи штатной фрейлиной цесаревны Марии Александровны ${ }^{7}$, высокомерно записала:

Нельзя не пожалеть о том, что императрице Марии АлексанАровне пришлось, ввиАу принятого обычая, получить в наслеАство весь этот устарелый и выцветший персона^ .

Как оказалось, в отношении Марии Фредерикс Тютчева ошиблась. М.П. Фредерикс не входила в тот круг, к которому принадлежала Тютчева, и так вспоминала о подготовке «великого переворота»:

4 Фрелерикс. 1997: 290.

5 Фредерикс. А. 16: 1-2.

6 Тютчева. 2004: 281.

7 По существующему правилу фрейлины вАовствующей императрицы переходили на службу к новой императрице. Таким образом, Мария Фредерикс в 1855 г. стала фрейлиной императрицы Марии АлексанАровны, супруги Александра II.

8 ФреАерикс. 1997: 281. 
В нашей придворной сфере, вне кабинета Государя, мало о том говорили, хотя и у Императрицы разные личности как например Тютчева, графиня Блудова и прочие и прочие очень суетились, желая тоже в этом играть роль, но все это делалось за затворенными Аверьми, нас грешных не допускали туда9.

Мария Фредерикс получала информацию о готовящихся реформах «в городе», в дружеском кругу вел. кн. Елены Павловны, кн. Голицыной. Неучастие в обсуждении политических событий при дворе не означало отстраненности от проблем общества и государства:

в уме моем все больше и больше созревала мысль ... слелаться сестрой милосердия и основать со временем Общину ... я сообщила в тайне эту мысль моему новому Аругу Марфе Степановне Сабининой, уговаривая ее илти на это поприще со мной, когАа после восьми условленных лет она оставит Авор ${ }^{10}$.

По сравнению с боготворимым Марией Фредерикс Николаем I Александр II представлялся ей человеком со слабым характером, которому не доставало силы и могущества для великих преобразований. Его трагическая гибель утвердила ее в этом. В своих воспоминаниях она называла его «царьосвободитель-мученик», но считала, что он обессмертил свое имя отменой крепостного права. И даже в этом она нашла повод восхититься Николаем I. Тот факт, что отмена произошла «без малейшей смуты» Фредерикс объясняла порядком, утвержденным в царствование последнего: «еще не ушло его могущество, существовавшее во всех слоях общества», это он подготовил «ту удивительную покорность в минуту такого громадного переворота, в котором ни один народ в мире не остался так спокоен»11.

9 Фрелерикс. А. 16: 28-29.

10 ФреАерикс. А. 16: 101.

11 ФреАерикс. 1997: 281. 
O 60-х гг. Мария Фредерикс писала: «повеяло слабостью и распущенностью», все стали воображать, что «сделались самостоятельными». «Дали нам и свободу мысли, и свободу действий, и свободу печати; словом бросились на все разом, думая этим ускорить развитие России. Бешеный поток этот, которому внезапно была открыта преграда и дана полнейшая воля, понятно, вырвался из своих пределов быстро и жестоко; сгоряча он стал все ломать, все тащить за собою. И, в конце концов, что же вышло из всего этого?»12- Цареубийство. «Вот к чему привело до сих пор наше ускоренное образование $60-$ х годов!» 13 .

Тем не менее, дух времени захватил ее. Перед ней женщиной привилегированного сословия, аристократкой открылись новые возможности, от которых она не захотела отказываться. Как бы Мария Фредерикс ни осуждала «бешенный поток» 60-х, она включилась в него и стала искать себе занятий «ради пользы отечества». Тем более, что она считала, что развитие и образование в обществе должны происходить от высшего сословия ... и служить примером простолюдину»14. Кроме того, неудачи Николая I она объясняла тем, что в окружении его было «мало честных людей, которые были бы искренне преданы своему отечеству и делу, забывающих себя ради пользы отечеству»15. Судя по всему, она взяла себе эту роль.

Разговорам и обсуждениям Мария Фредерикс предпочитала конкретные действия.

12 ФреАерикс. 1997: 279.

13 ФреАерикс. 1997: 279.

14 Фрелерикс. 1997: 279.

15 ФреАерикс. 1997: 279. 
Мысль быть сестрой милосердия так запала мне в душу, что когАа находилась в Петербурге, еще Ао моего знакомства с г-жой Сабининой, я езАила дежурить в КрестовозАвиженскую общину ... В амбулаторной Общины я работала поА непосреАственным руководством известной сестры милосердия Елизаветы Петровны Карцевой ... Утром я была испытуемой сестрой, а вечером я являлась на балы, театры и проч. светской барышней, и это в продолжение Аовольно многих ет $^{16}$.

Как следует из мемуаров, ее поведение находило понимание у императрицы, без разрешения которой Фредерикс не могла бы работать в Общине:

Об этих моих дежурствах знали только: Императрица, Великая княгиня Елена Павловна, фрейлина Ея г-жа Эйлер, через которую я все это себе и устроила и мой Аруг Княгиня Голицына, больше никто ${ }^{17}$.

\section{Марфа Степановна Сабинина (1831-1892)}

Марфа Степановна (ИлЛ. 3) имела более скромное происхождение. Она была из духовного сословия. Родилась в Копенгагене в 1831 г. в семье Стефана Карповича Сабинина - богослова, ученого, просветителя. Сабинин служил священником в храме русской дипломатической миссии в Копенгагене, затем был назначен духовником эрцгерцогини Марии Павловны Саксен-Веймарской ${ }^{18}$ и настоятелем Веймарского храма во имя равноапостольной Марии Магдалины. Научные интересы протоирея Сабинина были обращены не только на Священное писание. Он был полиглотом, знатоком древних и новых языков, занимался сравнительным языкознанием, изучал исландские письменные источники о русской истории, составил грамматику исландского языка.

16 ФреАерикс. А. 16: 101.

17 ФреАерикс. А. 16: 101.

18 Аочери Павла I, которая была замужем за наследным принцем Саксен-Веймарским Карлом Фрилрихом. 


\section{Юкина И.И. Праведные Марфа и Мария}

Как общественный деятель знакомил немецкое общество с достижениями русской культуры и науки. Совместно с г-ном Г. Требстом перевел на немецкий язык и издал двухтомник Пушкина. С другой стороны, он информировал русскую общественность о научных интересах и тенденциях в Европе.

Мать М. Сабининой - Александра Тимофеевна Вечезерова, дочь санкт-петербургского протоирея, знала немецкий, датский, французский, латынь, греческий, «еврейский» языки, занималась переводами, была прекрасной художницей. Их дом был центром интеллектуальной и общественной жизни в Веймаре. Историк М.П. Погодин, посетивший дом Сабининых в Веймаре записал:

Вот как я застал семейство: жена со старшей Аочерью писали картину масляными красками, которая могла бы с честью занять место в академическом классе; Аругая твердила урок на фортепьяно, какую-то сонату Моцарта, сыновья сидели за латинскими авторами, а отец читал католический журнал. Сколько образованности, ^юбознательности, вкуса, нашел я в этом семействе ${ }^{19}$.

Круг общения Сабининой с юности был широким и интернациональным: известные российские политические деятели, писатели и поэты, известные музыканты Европы. В дневниках за 1854 г. она описывает встречи с кн. А.М. Горчаковым - российским послом в Вене, В.П. Титовым - посланником в Штутгарте, кн. В.Ф. Одоевским, кн. С.П. Голицыным, кн. М.А. Вяземской (урожденной Столыпиной) и ее дочерью - женой посланника в Бадене, дочерью посла в Лондоне фон Брунова, бароном Мейендорфом, бароном Николаи, А.Г. Рубинштейном, поэтом кн. П.А. Вяземским, Н.В. Гоголем, Кларой Шуман, Г. Берлиозом, Ф. Листом и т.д.

19 Барсуков. 1893: 31. 
Другим кругом ее общения был двор эрцгерцогини Марии Павловны Саксен-Веймарской. Судя по дневникам, Марфа Сабинина придавала большое значение женскому образованию. В своих описаниях придворных дам она всегда подчеркивала степень их образованности и манеру поведения. 0 фрейлине М. фон Кеннериц писала:

она была очень образованная и выдающаяся по уму мичность, но Аержала себя очень скромно и в стороне 20 .

Водила дружбу со сдержанной и образованной камерфрау С.А. Роговой, сожалела о развлечениях приехавших в Веймар «дам большого Петербургского света».

Ко двору Марфа Сабинина попала не только в силу близости ее отца к эрцгерцогине, но в большей степени благодаря своему музыкальному таланту. Уже в 12 лет она стала членом музыкального кружка, созданного в Веймаре великой герцогиней Марией Павловной. Сабинина была виртуозной пианисткой и обладала редким или, как писали современники, «громадным голосом». Ф. Лист, высоко ценивший ее дарование, вызвался быть ее учителем музыки, а она стала его лучшей ученицей.

Ее жизнь была наполнена усиленными занятиями музыкой, науками, языками. Она сама сочиняла музыку, в 1854 г. издала свои первые романсы. Марфа Сабинина принимала активное участие в культурной жизни Веймара: посещала публичные лекции, концерты, общалась с музыкантами, участвовала в благотворительных концертах под управлением Ф. Листа и Г. Берлиоза, в деятельности певческого кружка и т.д., собиралась делать карьеру пианистки.

Сабинина. 1901: 1. 132. 


\section{Юкина И.И. Праведные Марфа и Мария}

В Россию она впервые приехала в 26 лет, дала несколько концертов в Петербурге и Москве, была представлена императрице Марии Александровне как виртуозная пианистка. Расслабленность русской жизни произвела на нее негативное впечатление:

БеспоряАочный образ жизни, ... сиАение Ао позАнего часа, позАнее вставание - все Аля меня было странно и я не могла к этому привыкнуть и жажАала работы и духовной жизни 21.

Она с радостью уехала в Веймар к своим занятиям и делам. Но императрица ее запомнила и вскоре через А.Ф. Тютчеву призвала Сабинину на службу при дворе в качестве преподавательницы музыки для своей дочери. Таким образом, Марфе Сабининой пришлось поменять артистическую карьеру на придворную:

30 сентября я получила официальную бумагу о моем назначении ... Я утешалась только мыслию, что восемь лет не вечность, а я приняла это место с условием, что по истечении этого времени я могу его оставить 22 .

В 1860 г. она приступила к обязанностям при дворе и прослужила оговоренные 8 лет. Соседкой по фрейлинскому коридору Зимнего дворца оказалась баронесса Мария Фредерикс.

\section{Придворные инициативы}

Реформаторский дух проник и во фрейлинский коридор. Идею о создании общества в поддержку воинов, проливших кровь за «любезное Отечество» высказала Марфа Сабинина. Осенью 1866 г. при дворе искали идею, как достойно ознаменовать прибытие в Россию невесты цесаревича принцессы

21 Сабинина. 1900: 6. 131.

22 Цит. по Рокина. 2015: 102. 
Дагмар. Лейб-хирург П.А. Наронович и лейб-медик Ф.Я. Карелль предлагали открыть в честь принцессы поликлинику с «новейшими усовершенствованиями по образцу берлинских». Сабинина настаивала на основании общества Красного Креста, существовавшего уже в большинстве европейских стран. Ее идея была принята.

Со свойственной педантичностью Марфа Сабинина изучила уставы европейских обществ Красного Креста. По результатам составила записку о необходимости создания в России Общества в поддержку воинов, сражавшихся во имя «общественной идеи». Баронесса Фредерикс полностью поддержала идею. Ее собственные мечты о сестринской деятельности совпадали с инициативой Сабининой.

14 декабря 1866 г. на квартире баронессы Фредерикс в Зимнем дворце состоялось первое заседание комитета 23 . Риторика обязательств общества и государства звучала в принятых документах:

не обязано ми само общество подумать о воинах и войти в положение тех, кого оно посылает умирать ради общественных интересов? ${ }^{24}$.

Отдельно было отмечено, что заимствование «чужой идеи» делает необходимым «облечь ее в свою самобытную, к местным данным приноровленную форму» и «только тогда эта идея станет вполне нашей русской, только тогда она привьется к нашему обществу и принесет плоды» 25 . На совещании была сформулирована цель будущего общества -

23 Помимо Сабининой и Фредерикс в засеАании приняли участие меАики: гл. воен. врач Х.Б. Риттер, П.А. Нарович, А.П. Нарович, Ф.Я. Каремль.

24 Алмазова. 1892: 4.

25 Алмазова. 1892: 4. 


\section{Юкина И.И. Праведные Марфа и Мария}

«облегчение участи раненых и больных воинов на поле сражения», а также обязанность «заготовлять мирным временем весь тот материал, о котором не время уже будет думать во время войны» 26 . Отдельно было прописано, что участие в обществе может принимать «каждый (курсив Н.И. Алмазовой), кому не чуждо человеколюбие» 27 . Судя по тексту под этим понималось, что в обществе могут участвовать женщины и представители разных сословий, т.е. организация изначально задумывалось как объединяющая всю нацию в ответственности перед его защитниками.

На следующий после заседания день Фредерикс и Сабинина доложили императрице о своей инициативе и испросили дозволения на учреждение общества. Императрица Мария Александровна откликнулась на идею и взялась ходатайствовать перед императором о разрешении, а также согласилась взять Общество под свое покровительство. При такой поддержке император, разумеется, согласился и дал распоряжение писать устав.

Написание устава оказалось процедурой сложной, требующей множества согласований и к тому же новой для учредительниц. Цели военных, врачей, духовенства и «общественности» в лице придворных дам расходились. «Военная партия» стремилась подчинить будущее общество военному ведомству. Партия «Marthe et Marie» (так они подписывали документы) настаивала на уставе частного общества, добровольно приходящего на помощь страждущим» (курсив Алмазовой - И.Ю. ${ }^{28}$. Помимо устава решили написать Воззвание к Русскому народу, с объяснением основной идеи Общества.

26 Алмазова. 1892: 4.

27 Алмазова. 1892: 4.

28 Алмазова. 1892: 8. 
В нем еще раз проговаривалось, что это частное Общество попечения о раненых и больных воинах, главной целью которого является содействие военной администрации во время войны в уходе за ранеными и больными воинами и доставление им, сообразно своим средствам, как врачебного, так и всякого рода вспомоществования ${ }^{29}$. Отдельно оговаривалось, что учредители Общества приглашают к участию «всех лиц, как богатых, так и бедных», «доступ в общество открывается всем и каждому, без различия звания, состояния и пола» 30 (курсив И.И. Юкиной). «Каждое пожертвование, даже самое незначительное, принимается с благодарностью» 31.

Привлечение в Общество учредителей тоже оказалось делом нелегким. По свидетельству современницы «дело было так ново, что точно боялись примкнуть к нему» 32 . Немногие верили в успех предприятия. «Я еще поверил бы успеху, если бы они были Марфой и Марией», - заявил один из рекрутируемых высокопоставленных военных чинов. - «Да ведь они и есть Марфа и Мария!», — ответила М. Кочетова одна из придворных участниц проекта.

Императрица в этом вопросе также пришла на помощь Marthe et Marie. Она определяла кандидатуры и коротко общалась с потенциальными учредителями, а затем давала распоряжения Марии Фредерикс продолжить с ними работу. Все понимали, что от того, станут ли влиятельные люди учредителями, зависит финансирование и судьба самого предприятия. В результате в СПб в число учредителей, помимо Фредерикс, Сабининой, лейб-медика Ф.Я. Карелля во-

29 Алмазова. 1892: 9.

30 Алмазова. 1892: 9.

31 Алмазова. 1892: 9.

32 Алмазова. 1892: 6. 


\section{Юкина И.И. Праведные Марфа и Мария}

шли: генерал-губернатор СПб Ф.Ф. Трепов, начальник Отдельного корпуса жандармов П.А. Шувалов, будущий министр Императорского двора кн. И.И. Воронцов-Дашков, министр иностранных дел, канцлер, князь А.И. Горчаков, такие известные врачи, как Н.И. Пирогов, С.П. Боткин, Н.Ф. Здекауэр и др. По свидетельству Алмазовой, чуть ли не каждый вечер в квартире баронессы проходили совещания.

Для расширения поддержки решено было привлечь Москву. И Москва откликнулась патриотически. Помимо московской знати интерес к делу проявили московские купцы. Генерал Тотлебен сообщал из Москвы, что «Дело находит великое сочувствие» 33 . Но вместе с тем генерал сообщил и неприятную новость - митрополит Московский и Коломенский Филарет категорически возражал против участия женщин в «управлениях» наряду с мужчинами, и предполагал их «совсем отделить» в дамские комитеты, которые можно было бы образовать при окружных и местных управлениях. В письме от 10 марта 1867 г. генерал Тотлебен писал фрейлине Фредерикс:

Высокопреосвященный не допускает, чтобы дамы заседали вместе с мущинами в управлениях; Аам предполагается совсем отАемить ${ }^{34}$.

Инициаторши, включая императрицу, не могли сдать свои позиции без боя. Фредерикс отвечалаТотлебену:

Высокопреосвященный Филарет видит залог Аля успеха Общества в резком отАелении дам от мужчин в засеАаниях. .... Без всякого сомнения, женщины, вне круга семейных обязанностей, должны Аовольствоваться скромной Аолей Аеятельности; но во всех госуАарствах, опередивших нас по пути просвещения, в скромной доле сей женщинам не отказывают действовать на поприще благо-

33 Цит. по Алмазова. 1892: 12.

34 Цит. по Алмазова. 1892: 11. 
творительности вместе с мужчинами. Какие соображения могли привести его высокопреосвященство к такому нелестному Аля Русских женщин мнению, не понятно, а Аля меня особенно было бы любопытно ознакомиться с ними ${ }^{35}$.

И далее: «государыня с сожалением усматривает из приложения к письму Вашему, что высокопреосвященный Филарет видит залог успеха Общества в резком отделении дам от мужчин в заседаниях». Но это не помогло.

23 марта 1867 г. генерал Тотлебен, вернувшийся из Москвы в Петербург, был принят Александром II и императрицей Марией Александровной и доложил, что мнение Филарета неизменно. Более того, митрополит пригрозил, что не останется членом организации и не напишет для него воззвания, если Общество образуется, не отделив дам от мужчин. Т.к. митрополит Филарет был влиятельной фигурой, и от него зависело мнение Москвы, которое в свою очередь имело огромное значение для всей империи, пришлось уступить. Пришлось отказаться от декларируемого ранее тезиса о «пользе и крайней необходимости» участия дам и их праве «быть членами в местных управлениях»36. Фрейлина Фредерикс сообщила в письме министру государственных имуществ генерал-адъютанту А.А. Зеленому, которого императрица планировала назначить руководителем Общества:

по поручению Государыни Императрицы имею честь передать Вам, что вопроса о дамах Ея Величество не берет на себя решить, а поручает это комиссии. Что же касается до Московских Аам, то Ея Величество изволила сказать, что они могут устраиваться по их собственному усмотрению37.

35 Цит. по Алмазова. 1892: 14-15.

36 Алмазова. 1892: 13.

37 Цит. по Алмазова. 1892: 17. 
Разочарование было сильным. Марфа Сабинина решила создать отдельное "русское женское общество» по примеру Frauen-Verein, членами которого были бы только дамы. Предполагалось, что в мирное время это женское общество будет действовать самостоятельно, заниматься подготовкой сестер милосердия и сиделок для Общества попечения о раненых и больных воинах и только в военное время поступит в его распоряжение. Но по здравому размышлению она сама отказалась от этой идеи, т.к. была уверена, что в ближайшее время этот вопрос разрешится в пользу дам. И действительно, в 1875 г. генерал-лейтенант А.К. Баумгартен написал баронессе Фредерикс:

Самый же важный успех Общества в том именно направлении, в котором вы, вместе с Марфою Степановною, так хлопотали: это привлечение женщин наравне с мужчинами к деятельности по Обществу. В новом уставе уже Аопущены в состав местных управмений и дамы, и в самом непродолжительном времени будет сАелано преАставление, чтобы в местных управлениях могли быть председатели или предсеАательницы по желанию. С утверждением этого представления, после восьмилетних колебаний, мы снова встанем в то положение, в котором хотели видеть наше общество вначале ${ }^{38}$.

Судя по тексту письма, генерал Баумгартен разделял идею женского участия. Хотя, конечно, не все были такого мнения. Алмазова объясняла инцидент «с дамами»в том числе тем, что «многие не понимали цели Общества, считали его правительственным, а не частным учреждением и не допускали женских деятелей в состав его членов» 39 . Также она свидетельствовала, что после инцидента между членами общества появилось недоверие, подозрение в интригах, дело затягивалось. В этот момент императрица проявила полити-

38 Цит. по Алмазова. 1892: 19-20.

39 Цит. по Алмазова. 1892: 21. 
ческую волю и, вызвав к себе генерал-адъютанта А.А. Зеленого, Мария Александровна прямо распорядилась, чтобы к 17 апреля 1867 г., ко дню рождения императора «все было кончено».

13 апреля 1867 г. устав Общества единогласно был принят учредителями. 28 апреля 1867 г. Государственный Совет одобрил его без всяких изменений. Вопрос об эмблеме Общества императрица обсудила коротко с Марией Фредерикс ей стала международная эмблема Красного Креста. Императрица напомнила, что Россия только что примкнула к Женевской конвенции 40 .

Таким образом, в результате энергичных усилий трех дам 3 мая 1867 г. император подписал указ об основании частного «Общества попечения о раненых и больных воинах» (с 1879 г. Российское Общество Красного Креста).

Созыв общего собрания только что учрежденного Общества в очередной раз спровоцировал гендерный конфликт. Переписка по этому поводу фрейлины Фредерикс и председателя Общества генерал-адъютанта Зеленого дает нам возможность понять позицию сторон по отношению к женской общественной активности в высших кругах российской власти. Она не была негативной - веяния времени уже проникли в европеизированную придворную среду. Из письма М. Фредерикс:

4022 августа 1864 г. на Аипломатической конференции в Женеве была принята Женевская конвенция об улучшении участи раненых и больных в Аействующих армиях - первый Аоговор в сфере гуманитарного права. Была принята эмблема - красный крест на белом фоне, что означало, согласно Конвенции, нейтралитет меАицинского учрежАения и его персонала. В странах, подписавших конвенцию, стали созАаваться общества Красного Креста. Россия подписала Конвенцию в 1867 г. 
Я только сейчас узнала от Ея Величества, что вы ей сказали, буАто Аамам совершенно не нужно быть на общем собрании ... Прошу вас объяснить, в чем Аело .... Все эти противоречия и препятствия, которые ставят Аамам в этом благотворительном деле, отбивают у меня всякую охоту ко всякой Аальнейшей деятельности в Аеле, бывшем Аля меня таким святым, начатым с таким усерАием. Я настаивала на присутствии дам на выборах, чтобы в самом начале не было разрыва Общества - разрыва, против которого я так упорно стояла ${ }^{41}$.

\section{В ответ Зеленый пишет:}

Весьма сожалею, что мой ответ Аал повоА преАположить о нежелании видеть Аам в нашем собрании; со своей стороны я напротив, желал бы полного участия дам в нашем совещании; и как весь успех нашего Аела, начатого дамами (курсив Алмазовой И.Ю.), вижу только в будущей их деятельности, то не мог не желать и присутствия их в собрании. ... Мне весьма прискорбно ... если Аамы охладеют к святому Аелу Общества: тогАа мы будем Аолжны отказаться от всех надежА на Аостижении цели (курсив Алмазовой - И.Ю.). Позвольте принести вам искреннюю благодарность за сообщенную заметку о неточности выражения в объяснении к уставу. Я воспользовался ею и изменил реАакцию42.

Собрание прошло при полном зале, баронесса Marie Фредерикс и Marthe Сабинина «блестящим образом» были выбраны почетными и пожизненными членами Общества.

Дальнейшая деятельность пошла по пути создания системы Дамских комитетов - губернских и провинциальных уездных. Образовавшиеся по инициативе дам, комитеты должны были получить разрешение у губернаторов и сообщить о своем образовании в Главное Управление Общества и императрице. Избирались они на два года. Основная их деятельность шла в направлении увеличения средств Общества, подготовки сестер милосердия, устройства мастерских для производства необходимых лазаретных приспособлений.

41 Цит. по Алмазова. 1892: 22.

42 Цит по. Алмазова. 1892: 22-23. 
Санкт-петербургский Дамский комитет считался «главным». Его возглавила камер-фрейлина, гр. Е.Ф. Тизенгаузен, вице-председательницей стала фрейлина баронесса М.П. Фредерикс. Кроме того, Фредерикс открыла отдел по складским делам, Сабинина стала ее помощницей. Совместными усилиями, при их организаторских возможностях и высоких связях, склад Marie et Marthe быстро обогащался. Состав отделения был отчетливо аристократическим: кн. М.А. Долгорукая, кн. А.В. Голицына, Р.И. Поссет, гр. М.А. Олсуфьева, гр. М.С. Стенбок, М.Л. Веймар, баронесса М.В. Розен, М.А. Кочетова, баронесса С.П. Фредерикс и др.

Общество попечения о раненых и больных воинах стало быстро набирать популярность и концентрировать значительные материальные средства. Участие в нем стало престижным и важным для военной и чиновничьей карьеры.

В 1868 г. Marie et Marthe оставили Санкт-Петербург. Восьмилетний срок службы при дворе М. Сабининой истек. Перед ними стояла задача осуществить мечту Фредерикс основать общину сестер милосердия. Решено было это делать в Крымском поместье М. Фредерикс «Джемиет». Правление складами приняла Ее Высочество Евгения Ольденбургская. Но связь с двором Marie et Marthe не прервалась. Вся их дальнейшая деятельность, включая участие в военных действиях в качестве сестер милосердия, в значительной степени координировалась императрицей. Тем более, что поместье «Джемиет» находилось недалеко от императорской резиденции в Ливадии и связь с государыней осуществлялась не только через депеши и телеграммы, но и при личных встречах.

В 1870 г. по приказу и на средства императрицы сестры милосердия Marie et Marthe, в недавнем прошлом придворные дамы, отправились на Франко-прусскую войну изучать 


\section{Юкина И.И. Праведные Марфа и Мария}

деятельность организаций Красного Креста в условиях боевых действий. Они посещали госпиталя и барачные лазареты в Германии и Франции, знакомились с транспортировкой раненых, на одном из первых в Европе санитарных поездов прибыли к осажденному Мецу. Обо всем виденном писали отчеты императрице 43 . За эту работу обе были удостоены знаками российского Красного Креста (ИЛЛ. 4) и вюртембергскими орденами Ольги.

В конце зимы того же года им было поручено устроить в Петербурге образцовый барачный лазарет. Со слов биографов Сабининой, императрица распорядилась следующим о бразом: «Но у меня нет на то ни денег, ни доктора, который мог бы помочь вам; устройте сами»44. Каким образом им удалось поднять необходимые ресурсы неизвестно. Не исключено, что баронесса Фредерикс в этот проект также вложила свои деньги. В нескольких источниках встречаются упоминания о ее расстроенных финансах в результате благотворительной деятельности. Но точной информации нет. Так или иначе, в конце марта 1871 г. Ее величество заложили первый камень в основание лазаретного барака на Песках. При лазарете был создан Дамский комитет, но возглавить его Сабинина отказалась, ссылаясь на работу по созданию сестринской общины. «Государыня очень огорчилась этим отказом, но по доброте своей отпустила Марфу Степановну» 45 .

В 1875 г. Крымская община сестер милосердия святого Благовещения была открыта, а в июле 1876 г. «праведные Марфа и Мария» получили депешу от императрицы, предписывающую отправиться в Сербию. С августа по ноябрь

43 ФреАерикс, Сабинина. 1870, 1871.

44 H.A. 1893: 512.

45 H.A. 1893: 512. 
1876 г. сестринская община работала в Сербии. Вернувшись в «Джемиет» Сабинина и Фредерикс стали строить лазаретный барак на случай русско-турецкой войны, что оказалось делом весьма своевременным. Война была объявлена в апреле 1877 г. На сей раз приказ императрицы отправил их в Румынию для использования германского опыта в организации работы санитарных поездов.

Здесь уровень управленческой работы оказался неизмеримо выше. Отношения между военно-медицинской администрацией, Обществом попечения и румынскими властями были напряженными. Полтора года Сабинина и Фредерикс занимались транспортировкой раненых от Дуная к русской границе. По имеющимся данным М. Сабинина предложила переправлять раненых по Дунаю на баржах, переоборудовав их в санитарные баржи по аналогу с санитарными поездами. Эту идею генерал Дрентельн и главный уполномоченный Красного Креста «нашли полезным для дела» и поручили это самой инициаторше - Сабининой. Тем более, что нужно было договариваться с Австрийской пароходной компанией, а у Сабининой и Фредерикс были высокие связи в Вене. В марте 1878 г. при содействии принца Александра Гессенского дело было блистательно урегулировано. После чего на верфях в Пеште под руководством все той же Сабининой обыкновенные баржи были переделаны в плавучие лазареты. Перестройка шести барж на 1300 мест с кухнями, кладовыми, помещением для персонала, отделением для офицеров на 48 мест, полным оснащением обошлась казне в 70 тыс. франков - мизерная сумма по оценки современников. В итоге с апреля и до глубокой осени 1878 г. санитарная флотилия из 6 барж и 2-х буксиров перевозила раненых под присмотром сестер Благовещенской общины. 
Осенью 1878 г. Marie et Marthe опять вернулись в «Джемиет», где продолжали работу в больнице сестринской общины, по меньшей мере, до 1882 г. Теперь больница обслуживала гражданских лиц. Ялта становилась популярным климатическим курортом, и «недостаточные» сограждане искали бесплатной квалифицированной медицинской помощи здесь.

Марфа Степановна Сабинина умерла в 1892 г. В 1901 г. баронесса Фредерикс обратилась с просьбой к Николаю II приобрести у нее имение «Джемиет», что и было сделано. Благовещенской общине были оставлены здания и земли, на которых они находились с 1875 г.

За свои заслуги М.С. Сабинина и М.П. Фредерикс были награждены знаками Красного Креста и вюртембергскими орденами Ольги (за Франко-прусскую войну). Точно известно, что Марфа Сабинина была награждена бронзовой медалью за русско-турецкую войну, командорским крестом сербского ордена Такова, румынским орденом Елизаветы и сербским орденом Красного Креста за 1876 год. Имела ли баронесса Фредерикс эти или еще какие-либо награды не известно.

Успех Российского Общества Красного Креста нельзя объяснить только высоким положением, волевыми усилиями и организаторскими способностями его основательниц.

Центральной идеей Общества была идея ценности человеческой жизни и ответственности государства и общества перед своими защитниками. Представляется, что на волне общественного подъема, который сопровождался консолидацией русской нации, мысль об ответственности государства перед подданными, человеческих правах самих подданных оказалась актуальной и встроенной сразу в несколько популярных дискурсов и трендов. Во-первых, в патриотическую идею о возрождении могущества русской армии после 
трагедии Крымской войны. Она соответствовала общественным требованиям об обновлении, введении новых форм организации и управления в армии, внимания и уважения к военнослужащим. Во-вторых, идея всесословности участия в «общественности», поддержки армии всей нацией также оказалась актуальной для эпохи формирования единого национального государства. В-третьих, выход женщин на арену публичной деятельности женское участие в «общественности» поддерживало развивающийся тренд автономизации личности, ее дееспособности и ответственности за свою судьбу. Напомним, что именно в это пореформенное время в России стало развиваться женское движение.

Таким образом, воплотив в себя идеи, надежды и тенденции модернизирующегося общества, Общество попечения о раненых и больных воинах (Российское Общество Красного Креста) получило широкую поддержу со стороны всех сословий и гендерных групп.

Что касается личной мотивации основательниц РОКК, но нет сомнений, что для них как христианок, идея сострадания, любви к ближнему, спасения своей души были важны и послужили отправной точкой деятельности. Также не вызывает сомнения, что Marthe et Marie понимали свою деятельность как средство общественного благоустройства и как форму женского общественного служения. Организация создавалась на новых для того времени основаниях добровольности, частного характера инициативы, всесословности и женского участия и лидерства.

В силу своего образования, вхождения в высокие круги России и европейских стран, знанию новейших общественно-политических тенденций и социальных инициатив, М.С. Сабинина и М.П. Фредерикс послужили проводником новых веяний, которые оказались «ко двору»в эпоху эман- 
сипации в России. Российское Общество Красного Креста стал практической реализацией изменения отношения к человеку — «простолюдину», признание за ним человеческих прав. Эти либеральные идеи повлияли на развитие законодательства в европейских странах и в России, и впоследствии получили название «первого поколения прав человека».

Создание Российского общества Красного Креста, подписание Россией Женевской конвенции (1867) способствовали утверждению в России новой отрасли права - международного гуманитарного права. 


\section{Список источников и литературы}

\section{ИсточнИКИ}

Алмазова. 1892 - Алмазова Н.И. К двадцатипятилетию Российского общества Красного Креста. М., 1892.

Сабинина. 1900 - Записки Марфы Степановны Сабининой // Русский архив. 1900, № 4-6, 8; 1901, № 1-4.

Тютчева. 2004 - Тютчева А.Ф. При дворе двух императоров. Воспоминания и дневники / Пер. с франц. Л.В. Гладковой - 3-е изд. М.: Захаров, 2004.

Фредерикс, Сабинина. 1870, 1871 - Фредерикс М.П., Сабинина М.C. Всеподданнейшие письма о посещение военносанитарных учреждений Германии // Вестник общества. 1870, № 10, 11; 1871, № 2.

Фредерикс. 1898 - Из воспоминаний баронессы М. П. Фредерикс // Исторический вестник. 1898, № 1. С. 52-87, 471-472; № 2. С. $455-484$.

Фредерикс. 1997 - Из воспоминаний баронессы М.П. Фредерикс // Николай I. Портрет на фоне империи. Тайны царского дв ора (из записок фрейлин). М.: Знание, 1997. С. 277-332.

Фредерикс. - Фредерикс М. П. Воспоминания старушки о дорогом прошлом. ОР РНБ. Ф. 432. Д. 15, 16.

\section{АИТЕРАТУРА}

Барсуков. 1893 - Барсуков Н. Жизнь и труды М. П. Погодина. СПб., 1893. Кн. 7.

Зимин. 2011 - Зимин И.В. Мария Петровна Фредерикс // Вопросы истории. 2011. № 7. С. 140-148

Линдермейер. 1992 - Линдермейер А. Добровольные благотворительные общества в эпоху Великих реформ // Великие реформы в России. 1856-1877. М., 1992. С. 283-300.

Мангейм. 1998 - Мангейм К. Проблема поколений // Новое литературное обозрение. 1998, № 2 (30). С. 7-47.

Н.A. 1893 - Н.А. Памяти М.С. Сабининой // Исторический вестник. 1893. Т. 51. № 2. С. 510-517.

Потенциал и пути развития филантропии в России. 2010 - Потенциал и пути развития филантропии в России. М.: Издат. дом Гос. универ. - ВШЭ, 2010. 
Рокина. 2015 - Рокина Г.В. Крымская история Марфы Сабининой // Восток - Запад. 2015, № 8. С. 96-109.

Рокина. 1991 - Рокина Г. В. Миссия С. Сабинина в Веймаре // Социально-политическая борьба в странах Европы и Америки в средние века и новое время. Йошкар-Ола, 1991. С. 120-129.

Рокина. 2005 - Рокина Г. В. Семья православного священн ика С. К. Сабинина (1789-1863) // Гендерные исследования в гуманитарных науках. Йошкар-Ола, 2005. С. 110-117. 


\section{И^^юстрации}

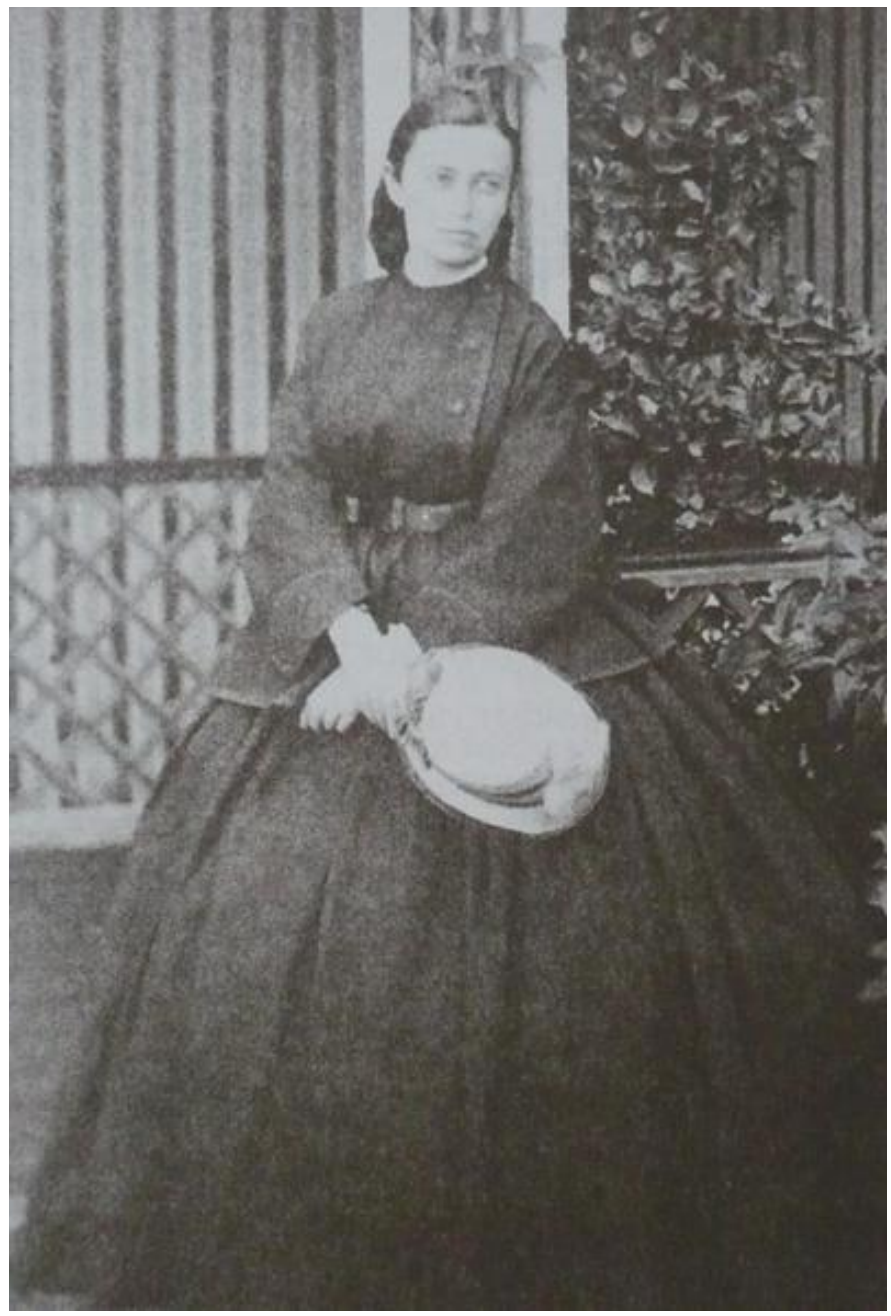

Им. 1. Мария Петровна Фредерикс (1832-1903). 
Юкина И.И. Праведные Марфа и Мария

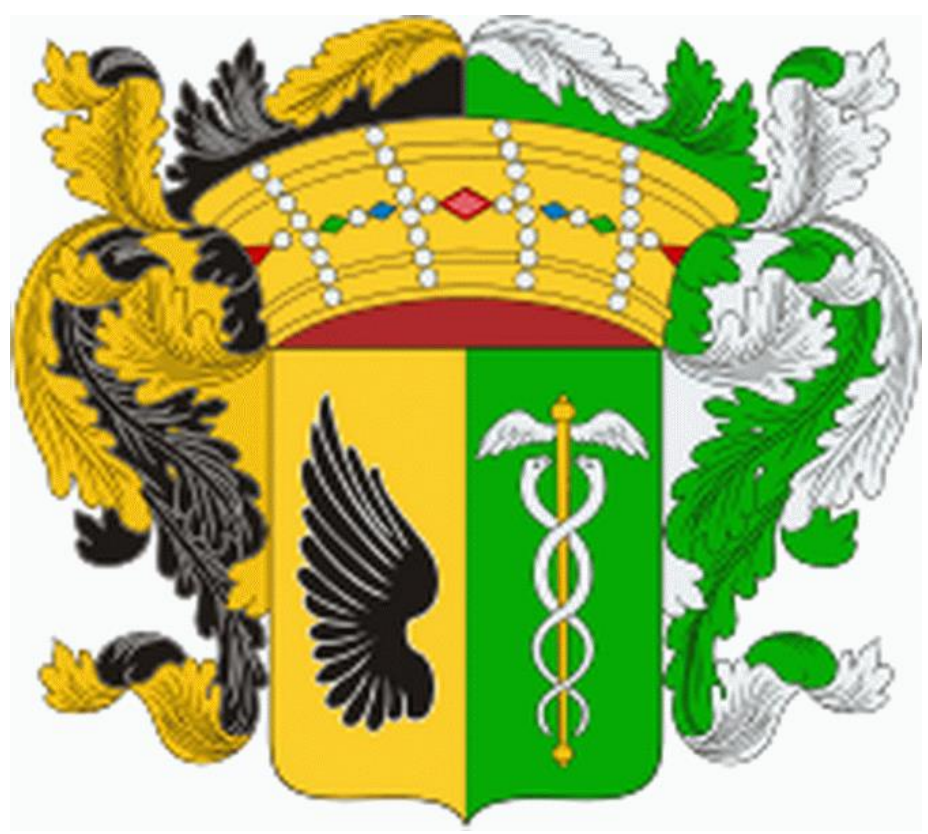

Им. 2. Герб баронессы Фредерикс. 
Гендерные репрезентации и социальные практики
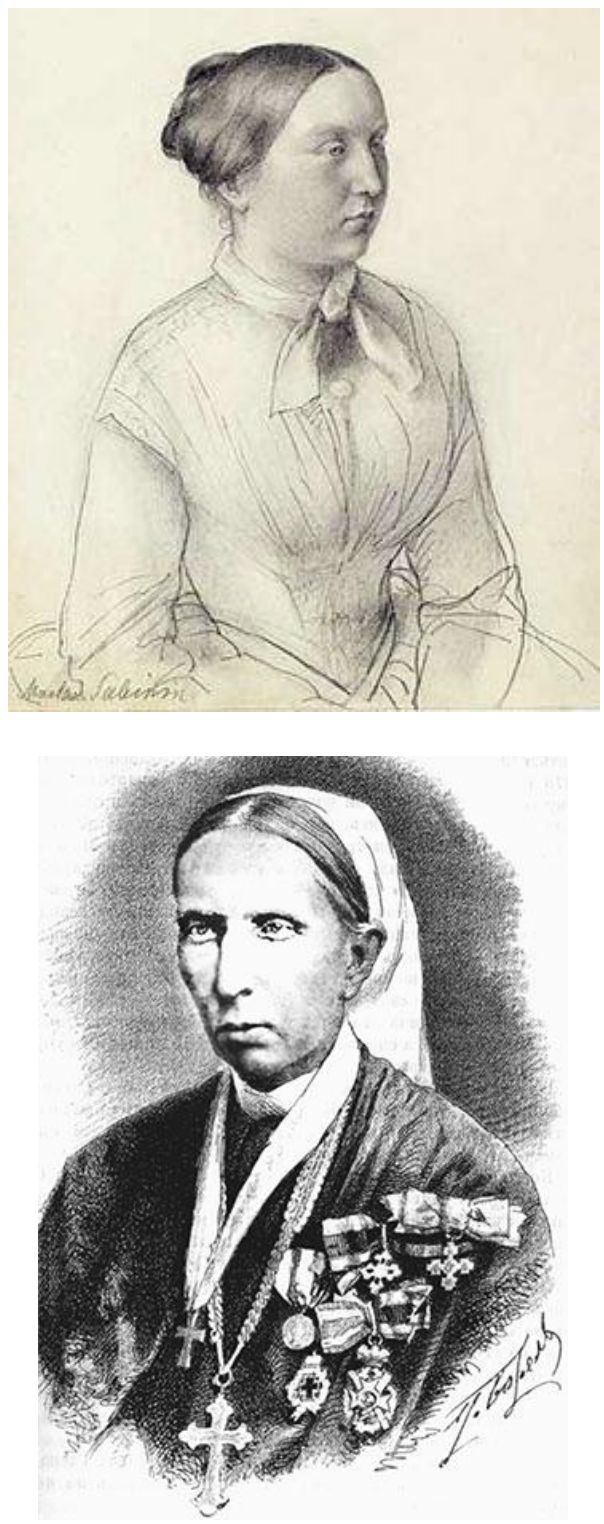

Им. 3. Марфа Степановна Сабинина (1831-1892). 
Юкина И.И. Праведные Марфа и Мария

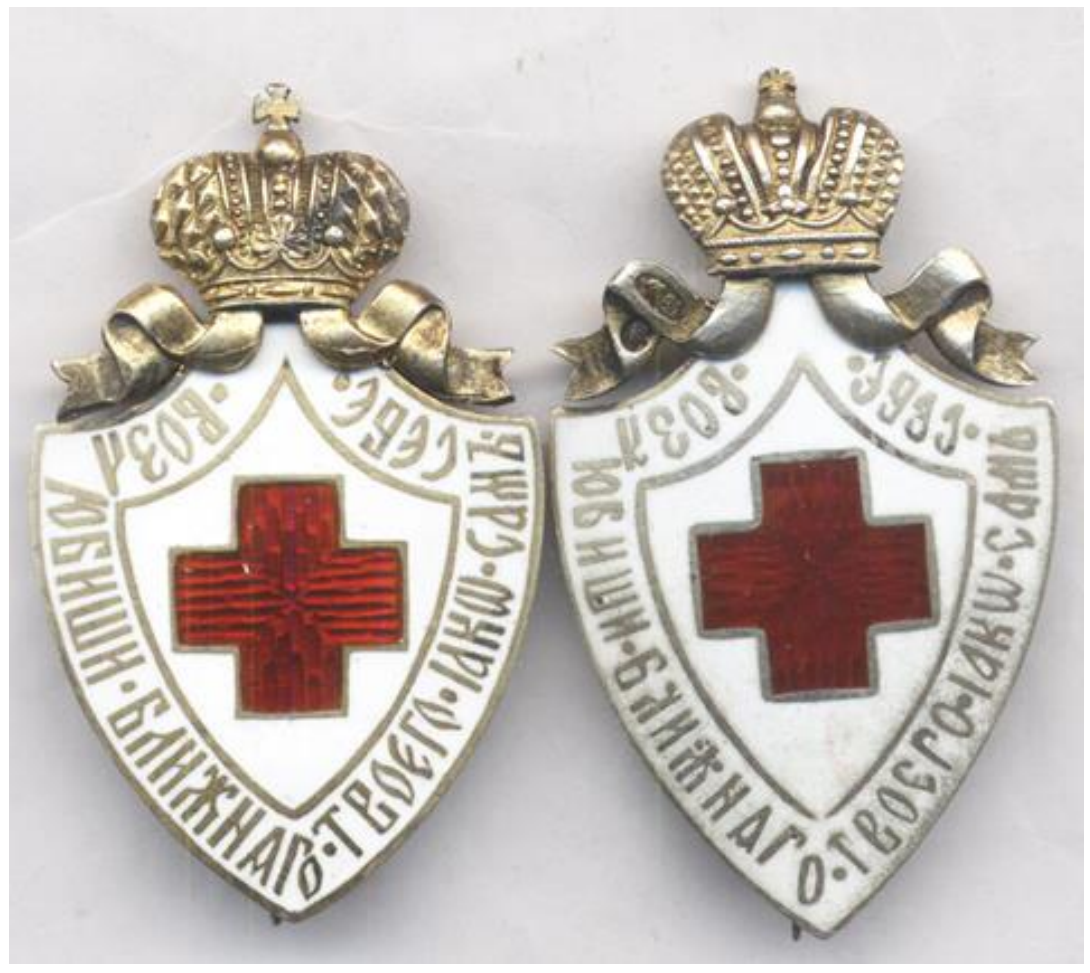

Им. 4. Знаки Российского Общества Красного Креста 